\title{
Transatlantica
}

Revue d'études américaines. American Studies Journal

2| 2017

(Hi)stories of American Women: Writings and Rewritings / Call and Answer: Dialoguing the American West in France

William Robertson's Unfinished History of America. The Foundation of the British Empire in North America and the Scottish Enlightenment

\section{Florence Petroff}

\section{(2) OpenEdition}

Journals

Electronic version

URL: https://journals.openedition.org/transatlantica/10326

DOI: 10.4000/transatlantica. 10326

ISSN: 1765-2766

\section{Publisher}

Association française d'Etudes Américaines (AFEA)

\section{Electronic reference}

Florence Petroff, "William Robertson's Unfinished History of America. The Foundation of the British Empire in North America and the Scottish Enlightenment", Transatlantica [Online], 2 | 2017, Online since 19 April 2019, connection on 31 January 2023. URL: http://journals.openedition.org/transatlantica/ 10326 ; DOI: https://doi.org/10.4000/transatlantica.10326

This text was automatically generated on 31 January 2023.

\section{c)}

Creative Commons - Attribution-NonCommercial-NoDerivatives 4.0 International - CC BY-NC-ND 4.0 https://creativecommons.org/licenses/by-nc-nd/4.0/ 


\title{
William Robertson's Unfinished History of America. The Foundation of the British Empire in North America and the Scottish Enlightenment
}

\author{
Florence Petroff
}

1 Only two years after his father's death William Robertson, the eldest son of the late doctor Robertson, sent an unfinished manuscript to his father's friends Hugh Blair and Alexander Carlyle, asking for their opinion. Hugh Blair was enthusiastic:

\begin{abstract}
I have read over with much pleasure the whole of that fragment of your Fathers intended History of British America, which you sent me, and I value it highly. [...] The composition, style \& whole execution I think not inferior to that of any other of his Historical books. I am therefore clearly of opinion that it ought to be preserved \& given to the Public; \& that it will do credit to his Memory. (Hugh Blair to William Robertson, January 21, 1795, NLS-National Library of Scotland-, MS 3944, f. 163)
\end{abstract}

Alexander Carlyle also gave his approval for publication:

My dear Sir, I return the Manuscript which I have perused with great pleasure. It appears to me perfectly ready for the Press and to possess all the Merit of your fathers narrative. (Alexander Carlyle to William Robertson, March 4, 1795, NLS, MS 3944, f. 165)

Thus comforted, W. Robertson junior started negotiating with a Scottish publisher based in London, the very son of his father's publisher, William Strahan (W. Robertson to A. Strahan, March 18, 1795, NLS, MS 3944, f. 167-173). As a result, two additional volumes of Robertson's The History of America were published in 1796. Book IX reveals the story of the foundation of Virginia and book X that of New England. They were meant to be the beginning of a much longer depiction of the beginnings and rise of all the English colonies in North America but the project had been abandoned about twenty years earlier on account of the American Revolutionary War.

William Robertson (1721-1793) had been writing the history of European colonization in North America as a sequel to his History of the Reign of Charles V. His work is a full- 
scale demonstration of the strength and extent of the British Empire compared to the long-established and once much more powerful Spanish Empire. His History of America first deals with the discovery of the New World, its conquest by Portuguese and Spanish conquistadores and the colonial system implemented by the Spanish monarchs. This is described and detailed at length in books I to VIII. In the following chapters the historian intended to draw a parallel with the foundation and rise of the English colonies in the seventeenth century so as to emphasize the achievements of the British Empire: "The dominions of Great Britain in America are next in extent to those of Spain" (Robertson, 1827 5). Yet the version published in 1777 was limited to the Spanish Empire. As he explained in the preface, Robertson had planned to delay publication until the whole masterwork was completed but finally renounced dealing with the British colonies.

5 Jeffrey Smitten has shown that Robertson was opposed to the independence of the Thirteen Colonies and has given a persuasive analysis of the reasons why the History of America remained unfinished in the context of the American Revolution (Smitten, 1990; 2018 167, 172, 178).

6 This paper explores the reasons why Robertson preserved the manuscripts from destruction. It contends that books IX and X of the History of America served other purposes besides glorifying the British Empire. In his depiction of early colonial America, Robertson asserted his sense of Britishness, analyzed the origins of the AngloAmerican controversy and pleaded for religious toleration.

7 First the article contextualizes the writing of the History of America. Then it shows that Robertson's work connects seventeenth-century history and the imperial crisis in the aim of giving an explanation for the conflict opposing the colonies and the metropole. The final part argues that William Robertson's description of New England's early history supports his commitment for toleration.

\section{A philosophical history of empires}

8 After his History of Scotland, 1542-1603 was published in 1759, William Robertson found himself in the position of a much congratulated and widely read historian within and beyond the English-speaking world. ${ }^{1}$ His other works, the History of the Reign of Charles $V$ (1769) and the History of America (1777) met with equal success. These apparently very diverse works are in fact consistent with the broad scheme of depicting the emergence of modern European commercial states and the spread of their empires in America. Robertson considered the increase of commerce and the expansion of empires as a sign of progress. He shared with other thinkers of the Scottish Enlightenment such as Adam Smith, David Hume, Adam Ferguson, and John Millar the conception of "stadial history," or "conjectural history." They believed all societies went successively through four stages of development. Native Americans were seen as belonging to the first stage, that of hunting and gathering, and did not know the notion of property. Europeans had already been through stage 2 (pastoralism and nomadism) and stage 3 (agriculture) and had started the fourth stage, the age of commerce (Phillipson, 59-60). Robertson's last and final opus, Historical Disquisition Concerning the Knowledge which the Ancients had of India describes pre-British India. These four history books were all best sellers which made Robertson the highest-paid Scottish author of the age as well as a widely admired historian. ${ }^{2}$ 
William Robertson hardly ever left Scotland. The history of the English colonies is for the most part based on narratives British travelers and settlers published in the sixteenth, seventeenth and eighteenth centuries which are mentioned in the footnotes. The writers who appear most often were sometimes personally connected to colonial enterprise. Richard Hakluyt's account of the first English settlements written in the 1580s aimed at convincing the Crown to support other expeditions to promote the development of transatlantic trade. He was himself a member of an association of merchants named the Clothworkers' Company, which paid him a pension. Another major source is the well-known John Smith (1580-1631), an explorer whose narrative of the foundation of Virginia brought him a new mission further north, in the region he baptized New England. Others were prominent colonists, such as Robert Beverley (1673-1722), a rich planter and politician, or Massachusetts governor Thomas Hutchinson (1711-1780). Many were Protestant clerics, such as Hakluyt, Cotton Mather (1663-1728), Daniel Neal (1678-1743), and William Stith (1707-1755). George Chalmers (1742-1825) is the only Scottish source. Unlike Robertson, most of them traveled to America. The Scottish historian clearly privileged narratives pieced together by European men of letters. He resorted to primary sources, but often gave an account of them without referring to them in the footnotes, unless they were part of a private collection such as Hutchinson's. ${ }^{3} \mathrm{He}$ did not stand apart from his contemporaries, the "philosophical travelers" as Jorge Canizares-Esguerra has labeled them, who increasingly dismissed indigenous testimonies and other first-hand sources to rely solely on European narratives (Canizares-Esguerra 13-22).

Impartiality was a key principle in Robertson's work. This is clearly the case in his first historical work, the broadly praised History of Scotland, in which he sought to detach himself from the conflicts of the sixteenth century and attempted to build an unbiased portrait of the divisive Mary, Queen of Scots. His method, based on the examination of different viewpoints, even those totally contradictory, was rooted in philosophy. As Smitten has shown, Robertson's principle of writing history impartially originated in the influence of Professor John Stevenson, who taught logic and rhetoric at Edinburgh University and introduced him to John Locke's thought. The student retained the necessity of counter-weighting seemingly opposed arguments in order to transcend a single perspective and thus approach the most probable interpretation, the one closest to the truth (Smitten, 1985 67-68). There are not many such controversial issues in his history of the North American colonies, except the question of mercantilism which will be discussed further in this paper.

11 Robertson's approach to history was also based on a thorough study of the variety of causes which lay behind past events (Womersley 497-506). The first part of book IX recalls how the English gradually developed their naval and commercial power and how their kings and queens progressively grew aware of the importance of a colonial empire. The historian provided a multiplicity of reasons to account for a decisive progress during Elizabeth I's reign which range from "the domestic tranquility of the kingdom" to "peace with foreign nations," "the queen's attentive economy, which exempted her subjects from the burden of taxes oppressive to trade," and finally emphasis on the development of the naval force (Robertson, 1827 17-18).

12 His enquiry into the complexity of human and non-human factors led him to discredit naturalists Buffon and de Pauw and their unique explanation for the alleged degenerative character of the Amerindians, meaning the climate. Instead he drew upon 
an array of moral and political causes to account for the then perceived backwardness and uncivilized condition of the Amerindian peoples. ${ }^{4}$ On the one hand Robertson paid homage to the qualities he perceived in the Natives of Virginia. Chief Opechancanough was said to possess "a fearless courage, great strength and agility of body, and crafty policy." On the other hand, the same leader and his people appeared as extremely deceitful when they plotted the massacre of the colonists who considered them as friendly neighbors and trusted them (Robertson, 1827 59).

Robertson's way of writing history was greatly admired across Europe and North America. Voltaire's tribute to his qualities of eloquence, knowledge, and impartiality seemed to sum up the opinion of the republic of letters. ${ }^{5}$ The 1777 version of the History of America was a success in Europe. Soon after the English edition came on the market, translations of Robertson's history of the Spanish Empire were undertaken first in Italian then in Spanish, Dutch, and French. The French version (L'histoire de l'Amérique, translated by Jean-Baptiste Suard) was so successful that it had to be reprinted several times: there were two editions in 1777, three in 1778, two in 1779, and another two in 1780 (Renwick 154-155). ${ }^{6}$ As for the history of British North America, it more directly targeted British readers. It was to be the narrative of the rise of their own empire related by a Briton of the North and a staunch unionist.

\section{A British vision of the American colonies}

The preface of the 1777 edition of the History of America claims: "The present state of the British colonies have induced the author to present a shortened version of what should have been a comparison between the rise of the Spanish and British American empires" (Robertson, 1777 v). William Robertson explained that he had been waiting for a stable government to be established in the colonies before completing his coverage of the foundations of the Thirteen Colonies. A few weeks after news of the vote of independence in Philadelphia reached Scotland, he wrote: "It is impossible to give any description of their political or commercial situation, or to [reflect] upon any speculation concerning their genius and talents while the contest between us remains undecided" (Robertson to Lord Hardwicke, August 26, 1776, British Library, Add MS 35350 , ff. $60-61)$. His plan was to later proceed with the history of the Portuguese colonies and the West Indies. This was never to be achieved, and apparently only the first two books were ever written.

In the prologue to books IX and X, his son discloses how these narratives survived (Robertson, 1827 iii-iv). It is mentioned that the minister chose to burn many of his papers in his last years, but preserved this unfinished history of English America. These pages must have meant a lot to their author, who tried to tackle the task several times. The manuscript was temporarily set aside in summer 1776 for four years. It was revised in August 1780 thanks to new sources shortly after the British seized Charleston. The coincidence seems to suggest that Robertson hoped for an honorable end to the war for Great Britain, and an opportunity for him to complete his project. The work was soon interrupted again, suffered modifications in 1781, and was eventually abandoned. Robertson justified his decision in a letter dated 1784, alleging bad health on the one hand, and an unfulfilled hope for a British military victory on the other:

I had written between two and three hundred pages of excellent History of the British Colonies in North America, I long flattered myself that the war might 
terminate so favourably for G. Britain, that I might go on with my work. But alas America is now lost to the Empire and to me, \& what would have been a great introduction to the settlement of British Colonies, will suit very ill the establishment of Independent states. (Robertson to Lord Hardwicke, March 8, 1784, British Library, Add MS 35350, ff. 70-71) ${ }^{7}$

His design was to relate the beginnings of the first two British North American colonies as part of an imperial scheme to overtake the Spanish Empire. The foundation and early developments he described were meant to be the premises of a glorious empire. However, in setting these colonies free, the American colonists severed the constitutional link with Britain, thus making Robertson's outlook meaningless. The historian would probably have completed his project, had the British Army been successful in its attempts to crush the rebellion. As it was not to be, he simply abandoned a design that proved absurd:

While they are engaged in civil war with Great Britain, inquiries and speculation about their ancient form of policy and laws, which exist no longer, cannot be interesting. The attention and expectation of mankind are now turned towards their future condition. (Robertson, $1777 \mathrm{v}$ )

Robertson's narrative is a British vision not only because it supports British colonization but also because of its strong unionist stance.

Over the second half of the eighteenth century America became increasingly important for Scotland. Thanks to the 1707 Treaty of Union, the English colonies in North America were opened to the Scots who were eagerly getting involved in colonial trade, administration, and cultural exchanges, thus making the Empire British. These colonies were seen as a way for Scotland's backward economy to reduce the discrepancy with England's. By the time Robertson was writing his book, Glasgow's “tobacco lords" had replaced their English counterparts as the main clients and suppliers of the planters in Maryland and Virginia. Until 1775 Scottish emigrants from the Highlands and the Lowlands were settling in America and created local Scottish communities. Many Scots corresponded with relatives and friends living across the Atlantic: merchants, colonial officers, Presbyterian ministers, and professionals such as teachers or doctors. The flows were heading both ways as the reputation of the University of Edinburgh attracted North American medical students (Devine 164-166; Landsman 9-10; Smitten, 1990 7-9).

Robertson's History of America is another example of the many ways in which the Scots took possession of the Empire. It was described as a legacy of the English, "a recompense due to those enterprising talents which prompted the English to enter early on the career of discovery, and to pursue it with persevering ardour." This legacy was shared by the Scots as the "dominions of Great Britain in America" (Robertson, 1827 5) had become theirs as well thanks to the Treaty of Union. Robertson's friend Reverend Carlyle shared the same view on the empire when he referred to "our ancient colonies" in a 1776 sermon (Carlyle 46). Books IX and X are not just celebrating the English colonies, but an Anglo-Scottish empire. 


\section{A history which echoes the Anglo-American controversy}

While describing the beginnings of the first two English colonies in North America, William Robertson focused on the relationship these colonies developed with the metropole. The historian has also showed the tensions which arose in the first decades of the colonies' existence. This description of the imperial relationship in the seventeenth century had echoes in the eighteenth century, especially on the issue of trading regulations.

William Robertson pointed out that trading regulations had been controversial ever since the beginning of colonization. Book IX mentions that the first royal charters in Virginia granted colonists very profitable conditions:

[James I] permitted whatever was necessary for the sustenance or commerce of the new colonies to be exported from England, during the space of seven years, without paying any duty; and, as a farther incitement to industry, he granted them liberty of trade with other nations, and appropriated the duty to be levied on foreign commodities, for twenty-one years, as a fund for the benefit of the colony. (Robertson, 1827 35)

Robertson explained how and why England set up a mercantilist system to her own benefit. When the Virginian planters started exporting tobacco and were in business with the Dutch in the early 1620 s, James I took action in order to direct profits toward London. As rulers gained experience in colonial expansion, they understood it was in their interest to control growing transatlantic exchanges. Starting with Cromwell, the Navigation Acts (1651-1696) set up rules in order to secure the monopoly of commerce with the colonies for the parent state and exclude the Dutch merchants and navy. The purpose was to bring taxes on imported colonial goods to the king, induce the development of a national fleet, and secure a monopoly on colonial emerging markets. Robertson concluded that this monopolistic "system," because it was designed to profit England alone, generated protests from the planters. ${ }^{8}$

He did not openly challenge the mercantilist system in his History of America even though he privately endorsed the rejection of mercantilism. His letter to Adam Smith shortly after the release of the latter's An Inquiry into the Nature and Causes of the Wealth of Nations (1776) stated it plainly: "I am happy to find my own ideas concerning the absurdity of the limitations upon the Colony trade established much better than I could have done myself" (W. Robertson to A. Smith, April 8, 1776, Mossner and Ross 192-193). William Robertson's circle of writers and scholars in Edinburgh were generally opposed to trade regulations. The Enlightened Scots considered what they called "the age of commerce" as the most advanced level of development in a society; therefore any attempt to set limits to free trade and thus prevent an increase of exchanges was seen as an obstacle to progress (Pocock 181). ${ }^{9}$

In dealing with mercantilism, Robertson's impartiality was tried. He was well aware that criticism of the Navigation Acts would be seen as disloyalty at a time when the colonists were fighting to free themselves from the regulations imposed by Great Britain.

Actually Robertson did not fully address the matter. He promised to scrutinize the arguments given by both sides further in the book, according to his usual method. Yet, that part, if it was ever written, is missing. The historian promoted both freedom and 
the empire, or freedom for the colonies within the empire, but this stance became more and more difficult to maintain as the colonies entered in open rebellion with the mother state. The colonists' dissatisfaction with mercantilism is not the only example of how Robertson's work echoes the eighteenth-century dispute with the metropole.

William Robertson's underlying assumption is that the first English settlers' call for liberty in their relation with London foreshadowed their revolt 150 years later. He pointed out that the colonies had developed their own spirit ever since their foundation and repeatedly emphasized the "spirit of independence" that typified New England's first settlers. For example the Puritans took no account of the royal charter the Massachusetts Bay Company had been granted in 1629:

Without regard to the sentiments of that monarch under the sanction of whose authority they settled in America, and from whom they derived right to act as a body politic, and in contempt of the laws of England, with which the charter required that none of their acts or ordinances should be inconsistent, they adopted in their infant church that form of policy which has since been distinguished by the name of independent. (Robertson, 1827 104)

The early settlers' spirit of independence was also apparent in the numerous violations of the regulations set up by the Crown, Robertson argued. In 1634 the freemen decided on their own to choose their representatives to a general court and later the colonies of Massachusetts, Plymouth, Connecticut, and Newhaven allied in a confederacy. Some even encroached on royal prerogative by creating a "coinage of silver money at Boston, stamped with the name of the colony, and a tree as an apt symbol of its progressive vigour" (Robertson, 1827 111-112, 126-128). Robertson concluded that the "spirit of innovation" and rebellion was at the root of colonization in New England:

But from the first institution of the company of Massachusetts Bay, its members seem to have been animated with a spirit of innovation in civil policy, as well as religion; and by the habit of rejecting established usages in the one, they were prepared for deviating from them in the other. (Robertson, 1827 107)

This suggests that the original plan of the Puritan colonists induced, or at least was one of the factors that produced, the break up with London in the following century. The independent nature of the colonists was a recurring theme in the Scottish press during the American Revolutionary War. An anonymous letter to the printer of the Caledonian Mercury claimed in 1774: "In the days of George the Third, the Puritans of New England are exactly the same people as their forefathers were in the days of Charles I. They are factious and turbulent, and even in opposition to legal government" ("To the printer" 1). Robertson believed the spirit of independence among the colonists was a driving force which the British state could only repress momentarily, and that the Thirteen Colonies were unerringly heading toward independence:

But, if they have any meaning, it must be that they should be free states, connected with us by blood, by habit, and by religion, but at liberty to buy and sell and trade where and with whom they please. This they will one day attain, but not just now, if there be any degree of political wisdom or vigour remaining. (W. Robertson to W. Strahan, October 6, 1775. Robertson, 1827 51-52)

He may have cast the shadow of his influence over Alexis de Tocqueville and George Bancroft. Both contended the development of new societies is inscribed in their foundations and saw the alleged spirit of liberty specific to the United States as a legacy of the Puritans who founded New England (Lacorne 25-27; Henneton 171). Robertson's History of British America provided an explanation for the Anglo-American controversy which suggested the Thirteen Colonies were responsible for the dispute. His work was 
related to another controversy in which Robertson was more deeply involved, the issue of the Catholic Relief Act which roused unrest in Scotland in 1778.

\section{An appeal for toleration}

One of the reasons why Robertson was very interested in the foundations of the colonies of New England lies in the principles and church organization which the Puritans instituted in the New World in the early seventeenth century. While painting the picture of New England society, he defined his ideal based on toleration and moderation. Toleration stood as a central concept for Robertson and the literati of the Scottish Enlightenment who led the Moderate party in the Presbyterian Church. Richard B. Sher defines the Moderates as "tolerant conservatives," both liberal in their views on religious freedom and socially and politically conservative (Sher, 1985 262). David Allan describes the party as "enlightened and elitist, [...] tied by interest and inclination to the political and landed classes" (Allan 71). William Robertson was their leader and presided over the annual meetings of the General Assembly of the Church of Scotland from 1762 to 1780 . This was the only body which acted as the head of the Kirk (the Church of Scotland), settling matters of church government and faith. The Moderates dominated the Assembly but their opponents in the Popular party had wider support among the ministers. The Moderates advocated a less suspicious attitude toward the Episcopalians than the one prevailing in the population and among many Presbyterian ministers who were unhappy with the Toleration Act imposed by Westminster in 1712 . With the Moderates' assistance, this religious minority progressively restored dioceses and renounced its Jacobite views to rally the Moderates' endorsement for the House of Hanover. Robertson's call for toleration became even more controversial in 1778 when he gave his approval to the Catholic Relief Bill in Scotland. This meant granting Scottish Catholics fundamental civil rights through the repeal of the anti-Catholic penal laws (Prunier 122, 134). ${ }^{10}$ His contribution to the debate in the General Assembly was an appeal for toleration:

[William Robertson] denied that the Protestant Religion was in any danger from the present bill in question [...]. The Principal, then, went into a historical account of the origin of the law now proposed to be repealed; shewed that it was a sanguinary, a cruel law; that nothing but the time in which it passed could be pled in justification of it. (Consideration of the Roman Catholic Bill" 3)

But the ministers of the evangelical faction of the Kirk, known as the Popular party, strongly opposed the bill. Their leader, John Erskine, claimed that the Scottish Catholics already enjoyed toleration, meaning they were not persecuted like the Protestants in France in the seventeenth century. Catholics, he insisted, were threatening and had to be repressed (Erskine). The Quebec Act of 1774 had made matters worse. Scottish evangelists such as John Erskine, William Thom, and James Murray believed Catholic powers were expanding their domination in North America (Mailer 263). ${ }^{11}$ These views were shared by a majority of ministers and a large part of the population who grew resentful against Principal Robertson. A broadside accused him of being a hypocrite whose career was based on flattery, and concluded: "This want of Zeal as a Clergyman, has hurt Religion in Scotland" (Character of a Certain Popular Historian, now Ministerial Agent, for Reconciling our Complaisant Clergy to the Church of Rome, 
NLS, MS 3118, folio 199). The Principal of Edinburgh University was even given a direct experience of intolerance when an angry anti-Papist mob threatened his house.

Not only was his call to toleration unpopular, but so were his more impartial views on religion. His comment that the founders of Protestant churches persecuted the Catholics was not understood by everyone, as a letter published in 1774 shows. The writer, who signed himself "a Protestant," pointed out at all the atrocities committed by the Catholic Church to conclude that Doctor Robertson could not draw a parallel, the Papists being much worse than the Protestants ("To the printer of the Caledonian Mercury" 3). Despite their leadership in the General Assembly, the Moderates failed to impose their ideal of a tolerant society due to a Presbyterian tradition inherited from the seventeenth century coupled with a strong prejudice against Catholics. The latter were too deeply associated on the one hand with the Stuart kings and their attempts at reconquering the throne, and on the other hand with the French, the enemy in the Seven Years' War and the American Revolutionary War after 1778 (Finlay 128-129; Colley 20-29). ${ }^{12}$

As a church leader Robertson could not impose toleration, but as an historian he strongly asserted his commitment to it. The Puritans who settled in New England in the early seventeenth century belonged to the group known as the Independents or the Brownists, the sect founded by Robert Browne in the 1580s. To these dissenters from the Church of England, the New World appeared as the land where they could build a society based on their religious ideals. Robertson recalled the persecutions these Puritans suffered due to the policies of Charles I and Archbishop William Laud, and contrasted them with the fanatical behavior of the same people once they arrived in the haven of America. To the eighteenth-century historian it was deeply ironic that the victims of intolerance should in turn become intolerant to fellow Protestants who did not fully share their views concerning church government and religious tenets:

But in the first moment that they began to taste of Christian liberty themselves, they forgot that other men had an equal title to enjoy it. [...] The very men who had themselves fled from persecution became persecutors; and had recourse, in order to enforce their opinions, to the same unhallowed weapons, against the employment of which they had lately remonstrated with so much violence. (Robertson, 1827 105)

Book IX of the History of America condemned the Puritans who banished those who differed in their religious beliefs or church organization, such as Ann Hutchinson (Robertson, 1827 114). ${ }^{13}$ New England's Puritan society clearly did not match Robertson's religious ideals-nor did its system of government, known to modern historians as the New England Way. ${ }^{14}$ Robertson clearly condemned the way freemen were defined:
A law was passed, declaring that none shall hereafter be admitted freemen, or be entitled to any share in the government, or be capable of being chosen magistrates, or even serving as jurymen, but such as have been received into the church as members. By this resolution, every person who did not hold the favourite opinions concerning the doctrines of religion, the discipline of the church, or the rites of worship, was at once cast out of the society, and stripped of all the privileges of a citizen. (Robertson, 1827 109) ${ }^{15}$

Absolute power was granted to ministers, who not only decided who deserved to be accepted in the church, but also determined who was given civil rights. Political rights were also subject to the arbitrary choice of religious leaders. 

chosen by God for redemption, those seen as "saints" by their peers who believed their behavior bore the signs of their divine election. He claimed these people were merely induced to assume "those austere and sanctimonious manners which were known to be the most certain recommendation" to the favor of the ministers, due to this noxious association of church government and control over the body politic (Robertson, 1827 110).

The society created by the Puritans in New England was reminiscent of seventeenthcentury Scottish society, dominated by a very austere and intolerant version of Presbyterianism. Robertson did not openly draw a parallel but his moderate stance was clearly grounded on the rejection of both these models of society dominated by strict orthodox Calvinists. There was nevertheless one American colony that fulfilled Robertson's religious ideal.

Rhode Island was composed of four towns founded by dissenters in Southern New England in 1636-1640: Providence, Portsmouth, Newport, and Warwick. Roger Williams, a dissenter banished from Salem, was the model of a religious leader for Robertson. Firstly, he stood out as uncommonly tolerant in Puritan New England:

His spirit differed from that of the puritans in Massachusetts; it was mild and tolerating; and having ventured himself to reject established opinions, he endeavoured to secure the same liberty to other men, by maintaining, that the exercise of private judgment was a natural and sacred right; that the punishment of any person on account of his opinions was an encroachment on conscience, and an act of persecution. These humane principles he instilled into his followers; and all who felt or dreaded oppression in other settlements, resorted to a community in which universal toleration was known to be a fundamental maxim. (Robertson, 1827 115)

Secondly, political and religious powers were totally separated in Rhode Island. The colony's organization was the exact opposite of the abusive form of government the Puritans had setup elsewhere. Religion and government were apart, which guaranteed the people total freedom of religion as well as civil rights-"the equality of condition among the members, as well as their religious opinions" (Robertson, 1827 115-116). A comparison with Robertson's sources shows that he developed his own vision of religious liberty in Rhode Island. Cotton Mather acknowledged the acceptance of other beliefs and the great diversity of religions in Rhode Island, but did not bring toleration to the fore.

I cannot learn that the First Planters of this Colony were agreed in any one Principle so much as this, That they were to give one another no disturbance in the Exercise of Religion; [...] I believe there never was held such a variety of Religions together on so small a Spot of Ground as have been in that Colony. It has been a Colluvies of Antinomians, Familists, Anabaptists, Antisabbatarians, Arminians, Socinians, Quakers, Ranters, every thing in the World but Roman Catholiks, and Real Christians, tho' of the Latter, I hope, there have been more than of the Former among them. (Mather Book VII 20)

41 George Chalmers referred to "measures, equally unnatural and unjust" of banishment which "laid the foundation of Rhode Island and other settlements" but mentioned neither Roger Williams nor religious toleration in this colony (Chalmers 163-164). As to Daniel Neal, he gave quite a different account of Roger Williams and believed that plurality in religion was dangerous: 
But after all a considerable Number of his Friends resolved to hazard their Lives and Fortunes with him; with these he travelled towards the South, and settled at a Place without the Jurisdiction of the Massachusetts, which they called Providence; here they incorporated into a Church, but proceeding from one Whimzy to another, they soon crumbled to pieces, every one following his own fancy till at last Religion it felt grew into Contempt, and the publick Worship of God was generally neglected. (Neal 141)

Notwithstanding his disapproval of the intolerant ways of most Puritans in America, Robertson painted a much more nuanced picture of the Puritans than Voltaire or Raynal, who deemed them fanatical. The Scottish minister did refer to the "fanaticism" of these "enthusiasts," but did not show contempt or hatred towards them, unlike the French Enlightenment thinkers (Robertson, 1827 95, 110). ${ }^{16}$

Robertson chose not to publish his account of the origins of British America, but preserved it because he sensed the narrative held interest despite the loss of the Thirteen Colonies. Like his contemporaries, Robertson emphasized continuity in time and believed the American Patriots were the direct heirs of the seventeenth-century Puritan settlers. Although the history of the British Empire in North America lasted only 70 years from the union to the revolution, it did play a part in bringing the Scots and the English together. Robertson also used his History of America to support the idea of toleration, a controversial concept in the context of competition between the Moderates and Scottish Evangelicalism. This unfinished history truly reflects the Moderate party in the Scottish Enlightenment-“pro-Hanoverian, Whig, and preaching a softer Calvinism that contained an important element of humanism and respect for civic virtue" (Broadie 22).

After the American Revolutionary War, Scotland's influence in America surged (Hook 129) and the History of America became widely popular in the Early Republic. Once enriched with books IX and X, it was serialized and printed in magazines from 1789 to 1791. New editions flooded the market from Philadelphia (1799, 1811-12, 1821), Walpole, New Hampshire (1801), and Albany (1822). As a result, Robertson became the most broadly read historian according to The North American Review in 1826 and his History of America is considered to have been the principal second-hand source in America until Irving and Prescott (Stimson 37-43). The enriched edition was remodeled into a handbook to which a school teacher named John Frost added a detailed set of questions designed to help students learn by heart (Broadie 49). Even though Robertson had taken a stand against the American Revolution, his writings became the groundwork for the history of the origins of the newly born United States of America and influenced several generations of American students. Children were also acquainted with his work through collections produced for their specific use such as the 1830 Stories of the Spanish Conquests in America: Designed for the Use of Children (Sedgwick et al.) and The Two Americas: Their Complete History, From the Earliest Discoveries to the Present Day in 1879 (Belknap et al.).

Robertson's success benefited from the context of far-reaching Scottish influence in the early national period. The Edinburgh literati of the Enlightenment provided the Americans with comforting and conservative doctrines based on the principles of a society controlled by its elites, trust in human progress, and moderate Protestantism. Thomas Reid's Common Sense philosophy, brought to America by eighteenth-century Scottish educators such as John Witherspoon, president of the College of New Jersey (later Princeton University), had a prevailing influence on society (Aspinwall 155). 
What is more, Robertson's work drew a portrait of the first settlers which the citizens of the United States could endorse: people in search of religious as well as commercial freedom.

\section{BIBLIOGRAPHY}

Works cited

Primary sources

BANCROFT, George. History of the United States of America, from the Discovery of the American Continent. Boston: Brown, 1854-1878.

BELKNAP, Jeremy, James GRAHAME, William ROBERTSON, David RAMSAY, and William HUBBARD. The Two Americas: Their Complete History, from the Earliest Discoveries to the Present Day. New York: H.S. Allen, 1879.

BEVERLEY, Robert. The History and Present State of Virginia, in Four Parts. London: R. Parker, 1705.

CARLYLE, Alexander. The Justice and Necessity of the War with our American Colonies Examined: A Sermon Preached at Inveresk, December 12, 1776, Being the Fast Day Appointed by the King, on Account of the American Rebellion. Edinburgh: J. Murray, 1777.

CHALMERS, George. Political Annals of the Present United Colonies from their Settlement to the Peace of 1763. London: Bowen, 1780.

"Consideration of the Roman Catholic Bill (The)." Caledonian Mercury, May 30, 1778, p. 3.

ERSKINE, John. A Vindication of the Opposition to the Late Intended Bill for the Relief of Roman Catholics in Scotland: In Which an Address to the People on that Subject, by the Reverend Dr. Campbell, Principal of Marischal College, Aberdeen, is Particularly Considered. Edinburgh: W. Gray and C. Elliott, 1780.

HAKLUYT, Richard. Divers Voyages Touching the Discoverie of America and the Islands Adjacent unto the Same Made First of All by our Englishmen, and Afterward by the Frenchmen and Britons. London: Thomas Woodcocke, 1582.

HUTCHINSON, Thomas. A Collection of Original Papers Relative to the History of the Colony of Massachusetts-Bay. Boston: Thomas and John Fleet, 1769.

---. The History of the Colony and Province of Massachusetts-Bay from the Charter of King William and Queen Mary in 1691 until the Year 1750. London: Richardson, 1765.

MATHER, Cotton. Magnalia Christi Americana: Or the Ecclesiastical History of New England, from its First Planting, in the Year 1620, unto the Year of our Lord 1698. London: Thomas Parkhurst, 1702.

NEAL, Daniel. The History of New-England: Containing an Impartial Account of the Civil and Ecclesiastical Affairs of the Country, to the Year of our Lord, 1700. London : A. Ward, 1747.

RAYNAL, Guillaume-Thomas, Abbé. Histoire Philosophique et Politique des Établissemens et $d u$ Commerce des Européens dans les Deux Indes. 1770. The Hague: Gosse fils, 1774.

ROBERTSON, William. The History of America. London: W. Strahan, T. Cadell, and J. Balfour, 1777. 
---. The History of America. Books IX and X: Containing the History of Virginia, to the Year 1688, and the History of New England, to the Year 1652. London: W. Strahan, Cadell \& Davies, 1796.

---. The Works of William Robertson, D.D., to Which is Prefixed an Account of the Life and Writings of the Author by Dugald Stewart. London: T. Cadell, 1827.

ROBERTSON, William, and John FROST. The History of the Discovery and Settlement of America: With an Account of his Life and Writings. To which are Added Questions for the Examination of Students by John Frost. New York: Derby \& Jackson, 1857.

SEDGWICK, Charles, William ROBERTSON, Leonard Crocker BOWLES, and Alonzo HARTWELL. Stories of the Spanish Conquests in America: Designed for the Use of Children. Boston: Leonard C. Bowles, 1830.

SMITH, Adam. An Inquiry into the Nature and Causes of the Wealth of Nations. London: W. Strahan and T. Cadell, 1776.

SMITH, John. The General History of Virginia, New England and the Summer Isles Together with the True Travels, Adventures and Observations, and a Sea Grammar. 1627. Glasgow: Maclehose, 1907.

STITH, William. The History of the First Discovery and Settlement of Virginia: Being an Essay towards a General History of this Colony. Williamsburg: William Parks, 1747.

TOCQUEVILLE, Alexis de. Democracy in America. Translated from the French by Henry Reeve. Cambridge, MA: Sever and Francis, 1862.

"To the printer." Caledonian Mercury, March 26, 1774, p. 1.

"To the printer of the Caledonian Mercury." Caledonian Mercury, February 5, 1774, p. 3.

Secondary sources

AHLSTROM, Sydney E. A Religious History of the American People. 1975. New Haven: Yale University Press, 2004.

ALLAN, David. Scotland in the Eighteenth Century: Union and Enlightenment. Harlow: Longman, 2002.

ASPINWALL, Bernard. "William Robertson and America." Eighteenth Century Scotland: New Perspectives. Eds. Thomas M. Devine and John R. Young. East Linton: Tuckwell Press, 1999, p. 152-176.

BUTLER, Jon. Awash in a Sea of Faith: Christianizing the American People. Cambridge, MA: Harvard University Press, 1990.

BROADIE, Alexander. The Scottish Enlightenment: The Historical Age of the Historical Nation. 2001. Edinburgh: Birlinn, 2012.

CANIZARES-ESGUERRA, Jorge. How to Write the History of the New World: Histories, Epistemologies, and Identities in the Eighteenth-Century Atlantic World. Stanford: Stanford University Press, 2001.

COLLEY, Linda. Britons: Forging the Nation, 1707-1837. New Haven: Yale University Press, 1992.

DEVINE, Thomas M. Scotland's Empire: the Origins of the Global Diaspora. 2004. London: Penguin, 2012.

FINLAY, Richard J. “Keeping the Covenant: Scottish National Identity." Eighteenth Century Scotland: New Perspectives. Eds. Thomas M. Devine and John R. Young. East Linton: Tuckwell Press, 1999, p. 122-134.

GERBI, Antonello. The Dispute of the New World, the History of a Polemic, 1750-1900. Translated from the Italian by Jeremy Moyle. Pittsburgh: University of Pittsburgh Press, 2010. 
HENNETON, Lauric. Liberté, inégalité, autorité. Politique, société et construction identitaire du Massachusetts au XVII siècle. Paris: Honoré Champion, 2009.

HOOK, Andrew. Scotland and America: A Study of Cultural Relations 1750-1835. 1975. Glasgow: Humming Earth, 2008.

KONTLER, László. Translations, Histories, Enlightenments: William Robertson in Germany, 1760-1795. New York: Palgrave MacMillan, 2014.

LACORNE, Denis. Religion in America: A Political History. Translated from the French by George Holoch. New York: Columbia University Press, 2011.

LANDSMAN, Ned. Scotland and its First American Colony, 1683-1765. Princeton: Princeton University Press, 1985.

MAILER, Gideon. "Nehemias (Scotus) Americanus: Enlightenment and Religion between Scotland and America." The Historical Journal, vol. 54, no. 1, 2011, p. 241-264.

McCUSKER, John. The Economy of British America, 1607-1789. Chapel Hill: North Carolina University Press, 1991.

MOSSNER, Ernest Campbell, and Ian Simpson ROSS, eds. The Correspondence of Adam Smith. Oxford: Clarendon Press, 1977.

PHILLIPSON, Nicolas. "Providence and Progress: An Introduction to the Historical Thought of William Robertson." William Robertson and the Expansion of Empire. Ed. Stewart J. Brown. Cambridge, UK: Cambridge University Press, 1997, p. 55-74.

POCOCK, J. G. A. Virtue, Commerce, and History: Essays on Political Thought and History, Chiefly in the Eighteenth Century. Cambridge, UK : Cambridge University Press, 1985.

PRUNIER, Clotilde. "Les catholiques en Écosse au XVIII ${ }^{e}$ siècle." Écosse des Lumières, le XVIII siècle autrement. Ed. Pierre Morère. Grenoble: Ellug, 1997, p. 105-149.

RENWICK, John. “The Reception of William Robertson's Historical writings.” William Robertson and the Expansion of Empire. Ed. Stewart J. Brown. Cambridge, UK: Cambridge University Press, 1997, p. $145-164$.

SHER, Richard B. Church and University in the Scottish Enlightenment: The Moderate Literati of Edinburgh. Edinburgh: Edinburgh University Press, 1985.

---. The Enlightenment and the Book: Scottish Authors and Their Publishers in Eighteenth-Century Britain, Ireland and America. Chicago: University of Chicago Press, 2006.

---. ed., The Works of William Robertson, 12 volumes. London: Routledge/Thoemmes Press, 1996.

SMITTEN, Jeffrey R. “Impartiality in Robertson's History of America." Eighteenth-Century Studies, vol. 19 , no. 1,1985 , p. 56-77.

---. The Life of William Robertson: Minister, Historian, and Principal. Edinburgh: Edinburgh University Press, 2018.

---. "Moderatism and History: William Robertson's Unfinished History of British America." Scotland and America in the Age of Enlightenment. Eds. Richerd Sher and Jeffrey Smitten. Edinburgh: Edinburgh University Press, 1990, p. 163-179.

STIMSON, Frederick S. "William Robertson's Influence on Early American Literature.” The Americas, vol. 14, no. 1, 1957, p. 37-43. 
VAN RUYMBEKE, Bertrand. L'Amérique avant les États-Unis. Une histoire de l'Amérique anglaise, 1497-1776. Paris : Flammarion, 2013.

WASZEK, Norbert. L'Écosse des Lumières. Hume, Smith, Ferguson. Paris : Presses Universitaires de France, 2003.

WOMERSLEY, D. J. “The Historical Writings of William Robertson.”Journal of the History of Ideas, vol. 47, no. 3, 1986, p. 497-506.

\section{NOTES}

1. Starting with Richard B. Sher's Church and University in the Scottish Enlightenment, scholars initiated a revival of interest in William Robertson (1721-1793) in the course of the 1990s. Due to studies dealing with the Scottish and European cultural developments of the eighteenth century as well as an effort to reprint Robertson's collected works (Sher, 1996), it now appears that he stood as one of the leading figures in the Scottish Enlightenment. He was a prominent figure as well, the Principal of Edinburgh University from 1762 to 1793 and an influential minister within the Church of Scotland. He was appointed Chaplain in Ordinary of Scotland (1761) and Historiographer Royal (1764).

2. Richard B. Sher reports that William Robertson's copyrights (sold in advance of publication) amounted to more than $€ 700,000$ or well over $\$ 1$ million in early twenty-first-century money (Sher, 2006 92, 214).

3. Thomas Hutchinson's Papers are mentioned on pages 96, 102,103,106, and 129 of William Robertson, The Works of William Robertson, volume III.

4. French naturalist Buffon in his Histoire Naturelle, générale et particulière, avec la description du Cabinet du Roi (1749-1789) stated that animal species of the New World were not only different but also smaller and weaker than those of the old World, due to a noxious environment. The prevalence of a cold and humid climate, said Buffon, promoted inferior forms of life such as insects and snakes, and kept the animals, including men, in an inferior and degenerate state. The belief in Europe's superiority and the influence of climate on men was shared by other philosophers, among whom Montesquieu, Raynal, Marmontel, and Hume. Buffon later developed a different approach, saying that the Indians were not degenerate but lived in an infant world. Following Buffon and commonplace prejudice against America, Dutch naturalist Cornelius de Pauw, in his Recherches philosophiques sur les Américains ou mémoires intéressants pour servir à l'histoire de l'espèce humaine (1768) took a much more radical stance, describing the Americans as hopelessly degenerate and incapable of any form of progress. This triggered a controversy with the defenders of the ideal "Noble Savage," particularly Pernety, the American Jesuits in exile in Italy, and Thomas Jefferson (Gerbi 34-79, 82-88, 154-156).

5. "You are eloquent, scholarly and impartial. I join with Europe in esteem of you" (Vous êtes éloquent, savant et impartial. Je me joins à l'Europe pour vous estimer; Voltaire, Letter to W. Robertson, February 26th, 1770, in Oeuvres complètes, tome XIII ${ }^{\mathrm{e}}$ Correspondance générale, tome $\mathrm{III}^{\mathrm{e}}$, Furne, 1838, 13. Quoted and translated by Renwick 163).

6. Concerning the translation of Robertson's work in German see Kontler.

7. The British Library identifies Lord Hardwicke as the recipient of the letter, but Jeffrey R. Smitten argues that the recipient is more likely Sir Robert Keith (Smitten, 1990 175, 179).

8. The mercantilist system did benefit England which could re-export colonial commodities such as tobacco or sugar and develop its manufactures to meet colonial demand. Yet the plantations also prospered thanks to the system which provided them with an exclusive market in England. Only in the course of the eighteenth century did the situation reverse when the colonial output overtook the capacity of Great Britain to absorb all the products and redistribute them in Europe. 
When colonists found themselves in need for new markets, discontent grew against the Navigation Acts and their stricter enforcement (Van Ruymbeke 151; McCusker 37, 46-49).

9. Adam Smith shared Adam Ferguson's conviction that because it favors commerce, division of labor in specialized tasks triggers prosperity and produces wealth (Waszek 91). Alongside the French physiocrats he pleaded for the end of protectionist legislation of any kind. He professed that the state should not interfere in the economy because in a free market the forces of supply and demand would result in a general improvement and prosperity. Adam Smith also maintained a political argument against restrictions on trade which constituted a "manifest violation of one of the most sacred rights of mankind" (Smith VII 2).

10. Catholics were a minority in Scotland, but were numerous in the popish bounds of the Western Isles. After the repression following the Jacobite rising of 1746, the government considered the Catholics were no longer a threat and the repeal of the anti-Catholic penal laws would allow the British military state to enlarge recruitment to Catholics (Prunier 116, 134).

11. According to the Evangelists the answer to the Catholic threat in North America was the independence of the United States. The issues of patronage and union, the American War of Independence, and Catholic relief were thus all interconnected and opposed the Popular party and the Moderates (Mailer 263).

12. Consequently the Scottish Catholics remained outlaws until 1793 when, due to anti-Christian Terreur in France, the Presbyterian and Catholic churches pacified their relations (Prunier 144-148).

13. Ann Hutchinson and a few of her followers were banished from Boston in 1637. The General Court of the Church thus put an end to the antinomian crisis which undermined the unity of the fragile colony of Massachusetts. According to John Winthrop, Ann Hutchinson rejected certain ministers but remained loyal to John Cotton and claimed that redemption did not solely rely on God's will. Lauric Henneton emphasizes that religious beliefs were tolerated unless they generated social unrest and thus endangered the cohesion of the group (Henneton 82-83, 497-500; Ahlstrom 153-154).

14. The Platform of Church Discipline of 1648 (otherwise known as the Cambridge Platform) led to the emergence of Congregationalist churches in New England (Van Ruymbeke 280).

15. Indeed it is estimated that at least two thirds of the colonists in New England were incorporated in a church as full members, except in Boston (Van Ruymbeke 278-280). In Boston in 1635 over half of the town's families were represented through the formal membership of either husband or wife in First Church, but the proportion decreased after the 1650s (Butler 57).

16. Denis Lacorne emphasizes Robertson's contribution to the rehabilitation of the Puritans which was further developed in the following century (Lacorne 14-15, 22-25).

\section{ABSTRACTS}

Historian and clergyman William Robertson never completed his history of British America. His initial project, that of glorifying the power of the British Empire, no longer made sense when the Thirteen Colonies became independent. This paper analyses the reasons why Robertson nevertheless preserved his manuscript, giving his son the opportunity to publish it posthumously. It explores the other designs of this narrative of the foundation of the first English colonies in North America. It argues that the Scottish historian developed a unionist approach of the empire and that he gave his History of America other meanings than just 
promoting colonization. Firstly Robertson explored the past of Virginia and New England in search for the roots of the eighteenth-century conflict between the Thirteen Colonies and the metropole. Secondly his study of New England society echoed the eighteenth-century controversy over the anti-Catholic laws in Scotland and supported his plea in favor of toleration.

L'historien et ecclésiastique William Robertson n'a jamais terminé son histoire de l'Amérique britannique. Son projet initial, qui était de rendre gloire à la puissance de l'Empire britannique, perdit tout son sens avec l'indépendance des Treize Colonies. Cet article analyse les raisons pour lesquelles Robertson a néanmoins conservé son manuscrit, permettant à son fils de le publier de façon posthume. Il s'agit d'explorer les autres desseins de ce récit de la fondation des premières colonies anglaises d'Amérique du Nord. L'article soutient que l'historien écossais a élaboré une vision unioniste de l'empire et qu'il donne à son Histoire de l'Amérique d'autres significations que la seule promotion de la colonisation. D'une part Robertson examine le passé de la Virginie et de la Nouvelle-Angleterre à la recherche des racines du conflit entre les colonies et la métropole au $\mathrm{XVIII}^{\mathrm{e}}$ siècle. En outre son étude de la société de Nouvelle-Angleterre résonne avec la controverse sur les lois anticatholiques en Ecosse au XVIII ${ }^{\mathrm{e}}$ siècle et plaide en faveur de la tolérance.

\section{INDEX}

Subjects: Hors-thème

Mots-clés: lumières écossaises, histoire de l'Amérique, abrogation des lois anticatholiques, tolérance

\section{AUTHOR}

\section{FLORENCE PETROFF}

Université Paris 8 Vincennes - Saint-Denis

florence.petroff@gmail.com 